\title{
THE SYNCHRONIZATION OF OESTRUS IN CATTLE WITH PROGESTAGEN-IMPREGNATED INTRAVAGINAL SPONGES
}

\author{
M. J. CARRICK AND J. N. SHELTON \\ Department of Animal Husbandry, \\ University of Sydney, Sydney, Australia
}

(Received 19th April 1966)

Summary. Two experiments were conducted to determine the efficacy for synchronization of oestrus and ovulation in cattle of $17 \alpha$-acetoxy- $9 \alpha-$ fluoro-11 $\beta$-hydroxyprogesterone ('Cronolone') administered by daily intramuscular injections or by intravaginal sponge.

In Experiment 1, cylindrical sponges were retained in $69.4 \%$ of heifers, while in Experiment 2 'bunched' sponges were retained in $82.8 \%$ of cows.

Daily intramuscular injection of $2 \mathrm{mg}$, or insertion of intravaginal sponges containing $100 \mathrm{mg}$, blocked oestrus and ovulation in the majority of animals. Within 5 days of termination of treatment in Experiment 1 oestrus occurred in $65.0 \%$ of heifers after intramuscular treatment and $55.6 \%$ after intravaginal treatment, while $53.5 \%$ of cows in Experiment 2 were oestrous within 7 days of sponge withdrawal. Synchronization of oestrus appeared more precise after intravaginal than intramuscular treatment in Experiment 1, but this was not significant. Of the oestrous animals, 95\% of heifers (Experiment 1) compared with $56.5 \%$ of cows (Experiment 2) were oestrous $1 \frac{1}{2}$ to $2 \frac{1}{2}$ days after termination of intravaginal treatment.

In Experiment 1, heifers were inseminated late in oestrus, resulting in a pregnancy rate 8 weeks after insemination of $53.8 \%$ of oestrous heifers following intramuscular treatment and 30.0\% following intravaginal treatment (difference not significant).

In Experiment 2, cows were inseminated 24, 36, 48, 60, 72 or $84 \mathrm{hr}$ after withdrawal of sponges regardless of the occurrence of oestrus. Twelve to 15 weeks after insemination the pregnancy rate was $23.0 \%$ for oestrous cows and $18.6 \%$ for non-oestrous cows (difference not significant). There was a significant $(P<0.05)$ quadratic effect of time of insemination with the highest pregnancy rate in cows inseminated 48 and $60 \mathrm{hr}$ after withdrawal of sponges $(30 \cdot 6$ and $29 \cdot 2 \%$ ).

Insemination of cows $24 \mathrm{hr}$ before observation of oestrus resulted in a pregnancy rate equal to that obtained from inseminations 0 to $12 \mathrm{hr}$ after observation of oestrus. This is suggestive of early ovulation relative to time of oestrus or an abnormal pattern of sperm transport. 
Whilst 'Cronolone' impregnated sponges are quite effective in suppression of oestrus and ovulation, the occurrence of oestrus and the fertility to insemination after treatment are unsatisfactory and not superior to those reported after intramuscular injection or feeding of progestagens.

\section{INTRODUCTION}

The ovarian cycle of the cow may be suppressed by progesterone injected daily in oil (Christian \& Casida, 1948; Ulberg, Christian \& Casida, 1951) or less frequently as a microcrystalline deposit (Nellor \& Cole, 1956) and by progesterone analogues administered in the feed (Hansel, Malven \& Black, 1961; Zimbelman, 1961). Lack of consistency in the occurrence of fertile oestrus after treatment and the practical problems of injecting or feeding large numbers of cows have precluded the field use of synchronization in artificial insemination programmes (Hansel, 1961; Lamond, 1964).

Robinson $(1964,1965)$ reported synchronization of oestrus and ovulation in sheep following removal of intravaginal sponges impregnated with $17 \alpha$ acetoxy- $9 \alpha$-fluoro-11 $\beta$-hydroxyprogesterone ('Cronolone', G. D. Searle \& Co.) which was shown by Shelton $(1964,1965)$ to have the same physiological action as progesterone with twenty-five times its potency. More recent work (Robinson, Salamon, Moore \& Smith, 1967) has shown that this technique enables simple and precise control of ovarian function in the sheep.

This paper describes two experiments designed to ascertain the efficacy of 'Cronolone' impregnanted intravaginal sponges for synchronization of oestrus in cattle. In the first, observations were made on the occurrence of oestrus during and after treatment with 'Cronolone' administered by daily intramuscular injection or in intravaginal sponges. Fertility to insemination at the post-treatment oestrus was assessed. In the second experiment similar observations were made on the control of oestrus, and inseminations were done at different intervals after termination of treatment.

\section{Animals}

\section{MATERIALS AND METHODS}

In Experiment 1, the animals were fifty-six Santa Gertrudis $\times$ Shorthorn heifers 15 to 20 months of age. In Experiment 2, ninety-six Friesian and ninetysix Australian Illawarra Shorthorn (A.I.S.) cows of mixed ages were used.

\section{Intravaginal sponges}

The sponges used in Experiment 1 were cylinders (diameter 21 in.; length 3 in.) of 800 Grade Polyester (density $=0.046 \mathrm{~g} / \mathrm{cm}^{3}$ ). These were impregnated with 100 or $200 \mathrm{mg}$ of 'Cronolone' by application of the required amount of compound in $100 \mathrm{ml}$ ethanol, which was then allowed to evaporate. These sponges were fitted with draw-strings for removal.

In Experiment 2, each pessary consisted of a bunch of twelve sheep sponges (Robinson, 1965) each $1 \frac{3}{8}$ in. in diameter and ten of which had been impregnated with 10 or $20 \mathrm{mg}$ of 'Cronolone' to give a total dose of 100 or $200 \mathrm{mg}$. 


\section{Insertion and removal of sponges}

The cylindrical sponges were inserted into the anterior vagina in heifers by use of a perspex tube of $1 \frac{1}{2}$ in. inside diameter and a perspex rod. The sponge was placed with string posterially in the tapered end of the tube which was then lubricated and inserted as far forward as possible in the vagina of the heifer. The sponge was expelled by use of a perspex rod, and tube and rod were then removed from the vagina taking care that the string extended back to the posterior part of the vagina. These sponges were removed by applying backward pressure with the gloved right hand in the rectum and applying traction to the draw string with the left hand.

In cows, the 'bunches' of sponges were inserted and removed with gloved and lubricated hand. The sponges were left in position for 18 or 19 days in Trial 1 (heifers) and for 21 days in Trial 2 (cows).

All sponges were liberally sprinkled before insertion with a powder containing Neomycin and Bacitracin.

\section{Conduct and design of experiments}

The first experiment was conducted during the period February to May 1965, at 'Deltroit', Tumblong, N.S.W. [King Ranch (Australia) Pty. Ltd]. Fifty-six heifers were examined by rectal palpation to ensure that all showed evidence of cyclic ovarian activity. Two groups each of eighteen heifers were treated with intravaginal sponges, containing $100 \mathrm{mg}$ 'Cronolone' in one group and $200 \mathrm{mg}$ in the other group. In these heifers, lost sponges were replaced daily by new sponges. Two further groups, each of ten heifers, received $2 \mathrm{mg}$ or $4 \mathrm{mg}$ 'Cronolone' by daily intramuscular injection. On the 18th and 19th days treatment was terminated for half the animals in each group. This was to avoid the possibility of a large number of animals requiring insemination at the one time. Heifers which exhibited post-treatment oestrus in the morning were inseminated that afternoon; those oestrous in the afternoon were inseminated the following morning. All heifers were inseminated with $1 \mathrm{ml}$ of Santa Gertrudis semen collected 6 weeks previously and stored at $-196^{\circ} \mathrm{C}$. This semen was evaluated as having a motility score of 3 ( 1 to 4 scale) and containing $40 \%$ live spermatozoa. Each dose contained a minimum of $30 \times 10^{6}$ live spermatozoa.

Experiment 2 was conducted in the South Coast dairying area of N.S.W. and was of mixed nested factorial design $(2 \times 2 \times 6 ; n=8 ; \mathcal{N}=192)$. Two intravaginal doses of 'Cronolone' were administered to two breeds of lactating (at least 6 weeks post-parturient) cows and each cow was inseminated at one of six intervals $(24,36,48,60,72$ or $84 \mathrm{hr})$ after termination of treatment. Six cows of one breed were used on each of thirty-two farms. On each farm all cows were treated at the same dose rate and one was inseminated at each time interval.

For insemination, Friesian and A.I.S. semen was used for Friesian and A.I.S. cows respectively. In each case all semen was from one collection, was stored at $-196^{\circ} \mathrm{C}$ and had a motility score after thawing of 60 to $70^{\circ}$. For both breeds each dose of semen contained approximately $140 \times 10^{6}$ spermatozoa. 


\section{Data recorded}

In Exp. 1, the animals were inspected for signs of oestrus every $3 \mathrm{hr}$ between 06.00 and 19.00 hours. Facilities did not permit observations at night. A heifer was recorded as oestrous only if she submitted to mounting by another heifer.

TABLE 1

EXPERIMENT 1. SPONGE RETENTION, OCGURRENCE OF OESTRUS DURING AND AFTER TREATMENT, AND PREGNANCY RATE 8 WEEKS AFTER INTRAVAGINAL OR INTRAMUSGULAR TREATMENT WITH 'CRONOLONE'

\begin{tabular}{c|c|c|c|c|c|c}
\hline \multirow{2}{*}{$\begin{array}{c}\text { Crronolone' } \\
\text { treatment }\end{array}$} & Treated & $\begin{array}{c}\text { Lost } \\
\text { sponges* }\end{array}$ & $\begin{array}{c}\text { Nestrous } \\
\text { during } \\
\text { treatment }\end{array}$ & $\begin{array}{c}\text { Ovulated } \\
\text { during } \\
\text { treatment }\end{array}$ & $\begin{array}{c}\text { Oestrous } \\
\text { after } \\
\text { treatment } \dagger\end{array}$ & $\begin{array}{c}\text { Pregnant } 8 \\
\text { weeks after } \\
\text { insemination }\end{array}$ \\
\hline $100 \mathrm{mg} \mathrm{i} / \mathrm{vag}$ & 18 & 5 & 0 & 0 & 11 & 4 \\
$200 \mathrm{mg} \mathrm{i} / \mathrm{vag}$ & 18 & 6 & 0 & 0 & 9 & 2 \\
$2 \mathrm{mg} \mathrm{i/m}$ & 10 & - & 0 & 0 & 5 & 2 \\
$4 \mathrm{mg} \mathrm{i/m}$ & 10 & - & 0 & 0 & 8 & 5 \\
Total & 56 & - & 0 & 0 & 33 & 13 \\
\hline
\end{tabular}

Note: $\mathrm{i} / \mathrm{vag}$, intravaginal sponge; $\mathrm{i} / \mathrm{m}$, daily intramuscular injection.

* Lost sponges were replaced daily by new sponges.

$\uparrow$ Within 5 days after termination of treatment.

Ovulation during treatment was determined by rectal palpation after termination of treatment. In Exp. 2, the recording of oestrus was done by the farmers, all of whom were accustomed to such observations for artificial insemination. All animals were examined for pregnancy by rectal palpation, the heifers 8 weeks after insemination and the cows 12 to 15 weeks after insemination.

TABLE 2

EXPERIMENT 1. FREQUENGY DISTRIBUTION OF INTERVAL FROM TERMINATION OF TREATMENT TO OBSERVATION OF OESTRUS

\begin{tabular}{|c|c|c|c|c|c|c|c|c|c|c|c|}
\hline \multirow{3}{*}{ Treatment } & \multicolumn{11}{|c|}{ No. of heifers in oestrus } \\
\hline & \multicolumn{10}{|c|}{ Days after termination of treatment } & \multirow[b]{2}{*}{ Total } \\
\hline & $\frac{1}{2}$ & 1 & & & $2 \frac{1}{2}$ & 3 & $3 \frac{1}{2}$ & 4 & $4 \frac{1}{2}$ & 5 & \\
\hline $100 \mathrm{mg} \mathrm{i} / \mathrm{vag}$ & 1 & 0 & 5 & 1 & 4 & 0 & 0 & 0 & 0 & 0 & 11 \\
\hline $200 \mathrm{mg} \mathrm{i} / \mathrm{vag}$ & 0 & 0 & 4 & 5 & 0 & $\mathbf{0}$ & 0 & 0 & 0 & 0 & 9 \\
\hline $2 \mathrm{mg} \mathrm{i} / \mathrm{m}$ & 0 & 0 & 0 & 1 & 1 & 0 & 1 & 1 & 0 & 1 & 5 \\
\hline $4 \mathrm{mg} \mathrm{i} / \mathrm{m}$ & 0 & 0 & 0 & 0 & 4 & 2 & 1 & 1 & 0 & 0 & 8 \\
\hline Total & 1 & 0 & 9 & 7 & 9 & 2 & 2 & 2 & 0 & 1 & 33 \\
\hline
\end{tabular}

Experiment 1

\section{RESULTS}

The results of Exp. 1 are summarized in Tables 1 and 2. During the period of treatment, sponges were retained in twenty-five of thirty-six heifers $(69 \cdot 4 \%)$. Three animals lost sponges twice during treatment. 'Cronolone', administered 


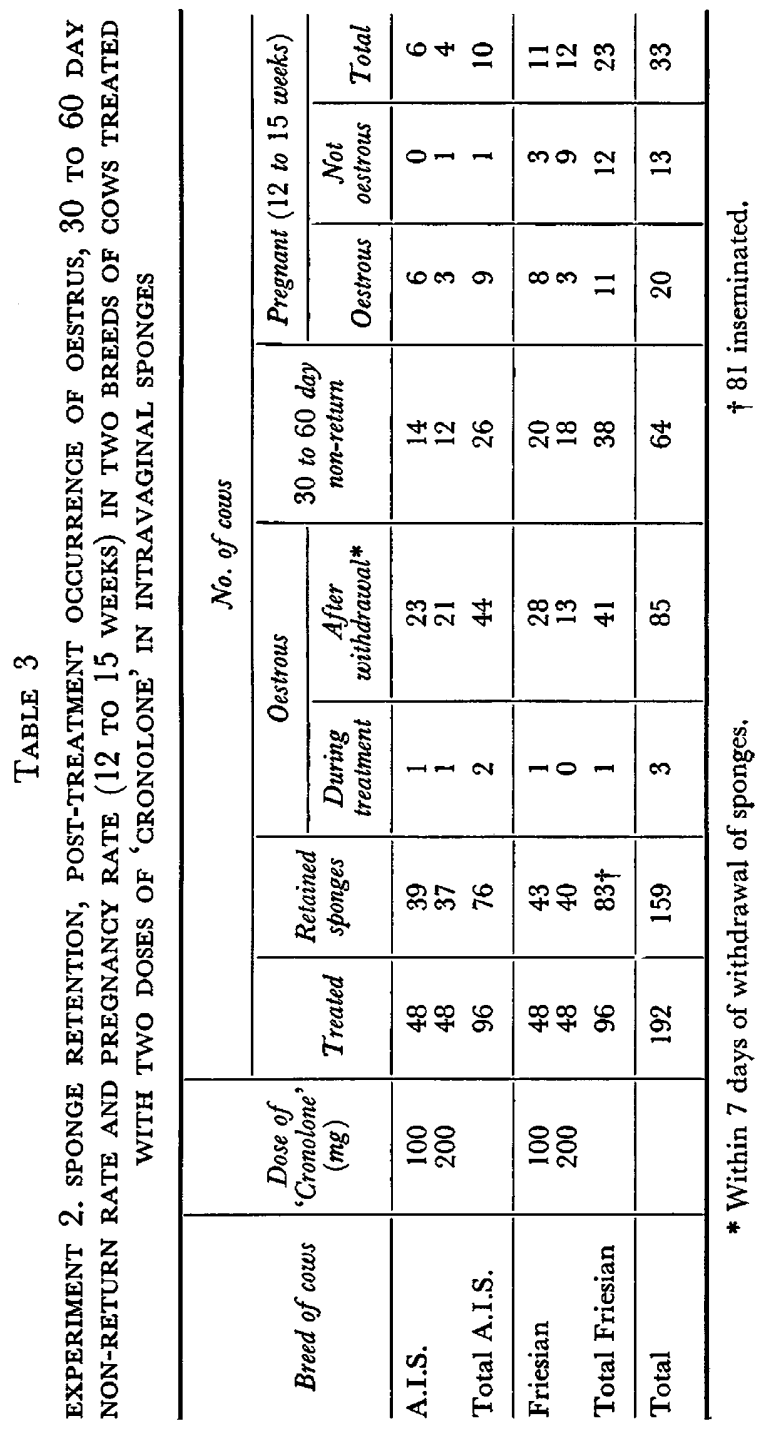


by intramuscular injection or in intravaginal sponges, suppressed oestrus and ovulation during treatment. Within 5 days after termination of treatment, oestrus was observed in twenty of thirty-six heifers $(55.6 \%)$ treated intravaginally and thirteen of twenty heifers $(65.0 \%)$ treated intramuscularly. Of the oestrous heifers, thirteen were pregnant on examination 8 weeks after insemination; six of twenty (30\%) after intravaginal treatment and seven of thirteen $(53.8 \%)$ after intramuscular treatment. There were no significant treatment effects upon oestrous response or pregnancy rate.

The frequency distribution of time interval from termination of treatment

TABLE 4

EXPERIMENT 2. SUMMARY OF ANALYSES OF VARIANGE OF GOWS IN OESTRUS AFTER TREATMENT AND COWS PREGNANT 12 TO 15 WEEKS AFTER INSEMINATION

\begin{tabular}{l|c|c|c}
\hline \multirow{2}{*}{ Factor } & \multicolumn{3}{|c}{ No. of cows } \\
\cline { 2 - 4 } & Total & Oestrous & Pregnant \\
\hline Breed & & & \\
A.I.S. & 76 & 44 & 10 \\
Friesian & 83 & 41 & 23 \\
$P$ & - & N.s. & $<0.05$ \\
\hline Dose of 'Cronolone' (mg) & & & \\
100 & 82 & 51 & 17 \\
200 & 77 & 34 & 16 \\
$P$ & - & $<0.05$ & N.s. \\
\hline Time of insemination (hr) & & & \\
24 & 24 & 12 & 4 \\
36 & 29 & 17 & 6 \\
48 & 26 & 15 & 8 \\
60 & 24 & 12 & 7 \\
72 & 31 & 15 & 7 \\
84 & 23 & 14 & 1 \\
$P$ linear & - & - & N.s. \\
$P$ quadratic & - & - & $<0.05$ \\
\hline
\end{tabular}

* Number of cows which retained sponges.

to observation of oestrus (Table 2) shows a tendency for earlier oestrus after intravaginal than after intramuscular treatment. However, this is not statistically significant $\left(\chi^{2}=8.87 ;\right.$ d.f. $\left.=5 ; P<0 \cdot 20\right)$.

\section{Experiment 2}

Table 3 shows results for sponge retention, occurrence of oestrus during and after treatment, 30 to 60 day non-returns, and pregnancy rate at 12 to 15 weeks after insemination. Table 4 is a summary of statistical analyses. Sponges were retained in 159 of 192 cows $(82.8 \%)$ and there were no treatment effects upon retention. Oestrus during treatment was observed in three cows with sponges retained.

Of the 159 cows in which sponges were retained, eighty-five $(53.5 \%)$ were observed in oestrus within 7 days of withdrawal of sponges. There was an effect 
of farms within breed of cows and dose of 'Cronolone' on the number of cows observed in oestrus $(F=1.57 ;$ d.f. $=28: 127 ; P \fallingdotseq 0.05)$. There was a greater incidence of oestrus after the $100 \mathrm{mg}$ dose of 'Cronolone' (fifty-one of eightytwo) than after the $200 \mathrm{mg}$ dose (thirty-four of seventy-seven) $(F=5.06$; d.f. $=1: 28 ; P<0.05)$.

The frequency distribution of interval from withdrawal of sponges to the observation of oestrus is shown in Table 5. Of eighty-five cows observed in oestrus within 7 days, thirty-four $(40.0 \%)$ were observed 2 days after withdrawal of sponges. An additional two cows were oestrous more than 7 days after termination of treatment. There were no significant treatment effects upon the distribution.

Of 159 cows which retained sponges (Table 3), 157 were inseminated 24 to $84 \mathrm{hr}$ after termination of treatment, and sixty-four $(40.8 \%)$ did not return to service within 30 to 60 days. However, only thirty-three $(21.0 \%)$ were pregnant 12 to 15 weeks after insemination. The pregnancy rate was greater in the Friesian (twenty-three of eighty-one) than in the A.I.S. cows (ten of

TABLE 5

EXPERIMENT 2. FREQUENCY DISTRIBUTION OF THE INTERVAL FROM WITHDRAWAL OF SPONGES TO THE OBSERVATION OF OESTRUS

\begin{tabular}{|c|c|c|c|c|c|c|c|c|c|c|c|c|c|c|c|c|}
\hline \multirow{2}{*}{$\begin{array}{c}\text { Breed of } \\
\text { cows }\end{array}$} & \multirow{2}{*}{$\begin{array}{c}\text { Dose of } \\
\text { 'Cronolone' } \\
(m g)\end{array}$} & \multicolumn{14}{|c|}{ Interval to oestrus (days) } & \multirow[b]{2}{*}{ Total } \\
\hline & & $\frac{1}{2}$ & 1 & $1 \frac{1}{2}$ & 2 & $2 \frac{1}{2}$ & 3 & $3 \frac{1}{2}$ & 4 & $4 \frac{1}{2}$ & 5 & $5 \frac{1}{2}$ & 6 & $6 \frac{1}{2}$ & 7 & \\
\hline A.I.S. & $\begin{array}{l}100 \\
200\end{array}$ & $\begin{array}{l}0 \\
0\end{array}$ & $\begin{array}{l}5 \\
2\end{array}$ & $\begin{array}{l}3 \\
2\end{array}$ & $\begin{array}{r}7 \\
11\end{array}$ & $\begin{array}{l}3 \\
0\end{array}$ & $\begin{array}{l}1 \\
3\end{array}$ & $\begin{array}{l}0 \\
0\end{array}$ & $\begin{array}{l}2 \\
2\end{array}$ & $\begin{array}{l}1 \\
0\end{array}$ & $\begin{array}{l}1 \\
0\end{array}$ & $\begin{array}{l}0 \\
0\end{array}$ & $\begin{array}{l}0 \\
1\end{array}$ & $\begin{array}{l}0 \\
0\end{array}$ & $\begin{array}{l}0 \\
0\end{array}$ & $\begin{array}{l}23 \\
21\end{array}$ \\
\hline Friesian & $\begin{array}{l}100 \\
200\end{array}$ & $\begin{array}{l}3 \\
0\end{array}$ & $\begin{array}{l}3 \\
1\end{array}$ & $\begin{array}{l}4 \\
0\end{array}$ & $\begin{array}{r}12 \\
4\end{array}$ & $\begin{array}{l}1 \\
1\end{array}$ & $\begin{array}{l}2 \\
2\end{array}$ & $\begin{array}{l}0 \\
0\end{array}$ & $\begin{array}{l}0 \\
2\end{array}$ & $\begin{array}{l}0 \\
0\end{array}$ & $\begin{array}{l}0 \\
1\end{array}$ & $\begin{array}{l}2 \\
0\end{array}$ & $\begin{array}{l}1 \\
0\end{array}$ & $\begin{array}{l}0 \\
0\end{array}$ & $\begin{array}{l}0 \\
2\end{array}$ & $\begin{array}{l}28 \\
13\end{array}$ \\
\hline Totals & & 3 & 11 & 9 & 34 & 5 & 8 & 0 & 6 & 1 & 2 & 2 & 2 & 0 & 2 & 85 \\
\hline
\end{tabular}

seventy-six $(F=4.95 ;$ d.f. $=1: \infty ; P<0.05)$. This difference arose because, whilst there was little difference in pregnancy rate between oestrous (twenty of eighty-five) and non-oestrous cows (thirteen of seventy-two), there was a greater number of pregnancies in non-oestrous Friesian than in non-oestrous A.I.S. cows (Table 3). Thus in the A.I.S., nine of forty-four oestrous and one of thirty-two non-oestrous cows were pregnant; in the Friesian cows the figures were eleven of forty-one and twelve of forty. This interaction was almost significant $(F=3.80 ;$ d.f. $=1: \infty ; P \fallingdotseq 0 \cdot 05)$.

Table 6 shows the number of cows of each breed pregnant 12 to 15 weeks after insemination at each time interval after termination of treatment with 100 or $200 \mathrm{mg}$ of 'Cronolone'. There was a significant quadratic effect of time of insemination upon pregnancy rate $(F=5.90$; d.f. $=1: \infty ; P<0.05)$, with the greatest percentage of pregnancies occurring in cows inseminated 48 or $60 \mathrm{hr}$ after the withdrawal of sponges. There was no effect of breed of cows or dose of 'Cronolone' upon the comparative success of insemination at different times.

Table 7 shows, for the eighty-five oestrous cows, the time of insemination 


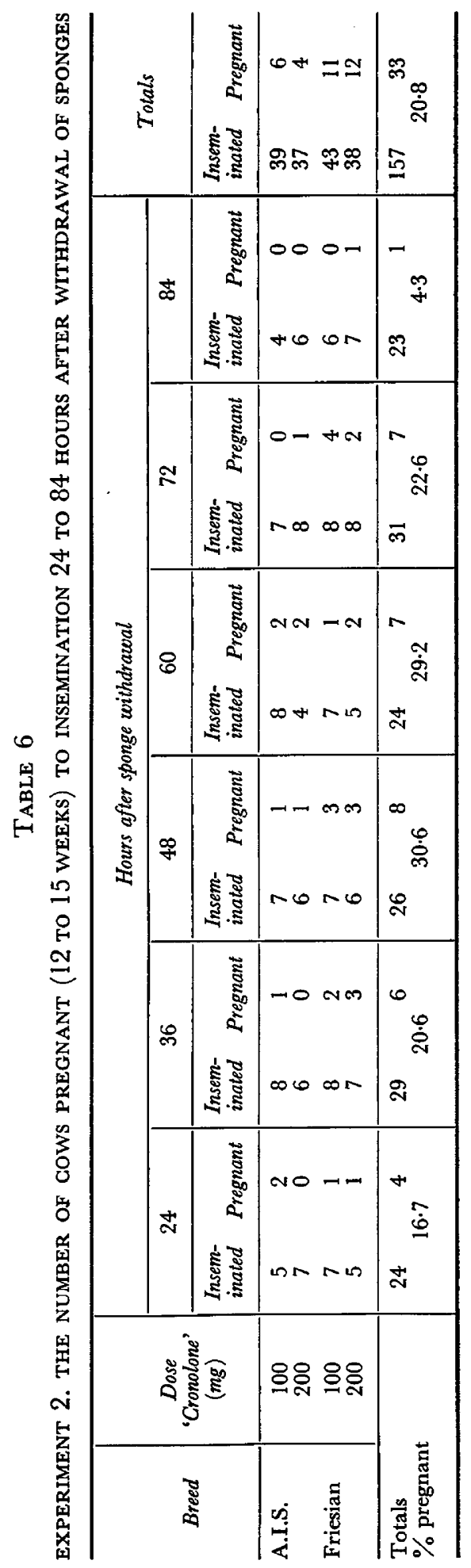


relative to observation of oestrus and the number pregnant for each time relationship. All the pregnancies were in those cows inseminated between $24 \mathrm{hr}$ before and $36 \mathrm{hr}$ after oestrus, with a sharp decline in pregnancy rate in cows inseminated more than $12 \mathrm{hr}$ after the onset of oestrus.

TABLE 7

EXPERIMENT 2. THE PREGNANCY RATE OF COWS RELATIVE TO THE INTERVAL BETWEEN OBSERVATION OF OESTRUS AND INSEMINATION

\begin{tabular}{|c|c|c|c|}
\hline \multirow{2}{*}{$\begin{array}{l}\text { Time of } \\
\text { insemination } \\
\quad(h r)\end{array}$} & \multicolumn{2}{|c|}{ No. of cows } & \multirow{2}{*}{$\stackrel{\%}{\%}$} \\
\hline & Inseminated & $\begin{array}{c}\text { Pregnant } \\
\text { (12 to } 15 \text { weeks) }\end{array}$ & \\
\hline $\begin{array}{c}\text { Before oestrus } \\
132 \\
120 \\
108 \\
96 \\
84 \\
72 \\
60 \\
48 \\
36 \\
24 \\
12 \\
0\end{array}$ & $\begin{array}{r}1 \\
1 \\
0 \\
0 \\
3 \\
3 \\
1 \\
2 \\
5 \\
8 \\
7 \\
19\end{array}$ & $\begin{array}{l}0 \\
0 \\
0 \\
0 \\
0 \\
0 \\
0 \\
0 \\
0 \\
3 \\
3 \\
7\end{array}$ & $\begin{array}{c}0 \\
0 \\
0 \\
0 \\
0 \\
0 \\
0 \\
0 \\
0 \\
37 \cdot 5 \\
43 \cdot 0 \\
36 \cdot 8\end{array}$ \\
\hline $\begin{array}{l}\text { After oestrus } \\
\quad 12 \\
24 \\
36 \\
48 \\
60\end{array}$ & $\begin{array}{r}12 \\
7 \\
11 \\
2 \\
3\end{array}$ & $\begin{array}{l}5 \\
1 \\
1 \\
0 \\
0\end{array}$ & $\begin{array}{c}41 \cdot 7 \\
14 \cdot 3 \\
9 \cdot 1 \\
0 \\
0\end{array}$ \\
\hline Total & 85 & 20 & 23.5 \\
\hline
\end{tabular}

\section{DISCUSSION}

The progestagen, $17 \alpha$-acetoxy- $9 \alpha$-fluoro- $11 \beta$-hydroxyprogesterone, will block oestrus and ovulation in heifers when administered at the rate of $2 \mathrm{mg} / \mathrm{day}$ by intramuscular injection or at a dose of $100 \mathrm{mg}$ by intravaginal sponge. Failure to palpate functional corpora lutea at termination of treatment does not exclude the possibility of ovulation early in treatment but strongly suggests that ovulation was inhibited. A similar intravaginal dose blocked oestrus and presumably ovulation in most cows. In Exp. 2, ovarian palpation was not carried out after termination of treatment to avoid risk of adversely affecting ovulation and fertilization. However, previous observations (Shelton, unpublished data) show that ovulation is blocked during treatment with intravaginal sponges impregnated with 'Cronolone'. Thus the technique is effective in both the cow and the ewe (Robinson, 1964, 1965) for the blocking of oestrus and ovulation.

The retention of cylindrical sponges in the heifer was not satisfactory, whereas in cows the retention of 'bunched' sponges approached a satisfactory 
level. Nevertheless, this type of sponge may not be satisfactory for heifers because of difficulty in removal from a small vagina.

Whilst in both experiments the occurrence of oestrus after withdrawal of sponges $(58.9$ and $53.5 \%$ ) was low, the pregnancy rate in non-oestrous cows in Exp. 2 indicates that many of these animals ovulated. Variability in oestrous response has been discussed by Lamond (1964) who reported that, in some instances, as few as $10 \%$ of lactating beef cows showed oestrus. In some cases this may be due to difficulty in detection of oestrus (Donaldson \& Larkin, 1966) but in the second experiment reported here the methods of observation were those which have been found quite reliable in untreated lactating cows. The possibility of greatly shortened duration of oestrus resulting in failure of detection should be investigated. Carrick and Shelton (unpublished data), whilst showing that progesterone pretreatment affects the sensitivity of heifers to oestrogen, have obtained oestrus of less than $3 \mathrm{hr}$ duration in some cases. These unusually short periods of oestrus in spayed and entire animals may be due to inadequate pre-conditioning with progesterone or to insufficiency of oestrogen.

In the first experiment, synchronization of oestrus following intravaginal treatment was quite precise. Of twenty heifers observed in oestrus nineteen $(95 \%)$ were oestrous $1 \frac{1}{2}$ to $2 \frac{1}{2}$ days after termination of treatment. In Experiment 2 , Iess precision was obtained; of eighty-five cows observed in oestrus, fortyeight $(56.5 \%)$ were oestrous $1 \frac{1}{2}$ to $2 \frac{1}{2}$ days after treatment and seventy $(82.3 \%)$ within 3 days after treatment. In the latter there was no effect of breed of cow or dose of progestagen. The effect of lactation on post-treatment oestrous response cannot be assessed from these experiments.

The low fertility in Experiment 1 suggested that the time of insemination (approximately $12 \mathrm{hr}$ after onset of oestrus) might not have been optimal for fertilization. However, in Experiment 2, insemination at other times did not improve fertility. While the numbers of cows are not large enough to be conclusive, the data of Table 7 indicate that fertility was as good to insemination $24 \mathrm{hr}$ before oestrus as $12 \mathrm{hr}$ after oestrus. Whereas Trimberger (1948) obtained no conceptions following insemination before oestrus, Vandeplassche \& Paredis (1949) reported 50\% conception in twenty-two cows inseminated 3 to $24 \mathrm{hr}$ before oestrus. Thus the normality of our results is not clear, but it might be concluded that fertility to insemination before oestrus has not been decreased while that at or after oestrus has been depressed. There are three possible explanations of these results. First, the low fertility overall may have 'masked' the effect of time of insemination relative to onset of oestrus, but this explanation is not supported by the quite normal decline in pregnancy rate from inseminations done more than $12 \mathrm{hr}$ after the observation of oestrus. Second, there may be a tendency for ovulation to occur early, relative to oestrus, in progestagen-treated cows. Shelton \& Moore (1967) suggested a similar phenomenon in progestagentreated ewes. Third, progestagen treatment may be followed by an abnormal pattern of sperm transport as suggested for the ewe by Quinlivan \& Robinson (1967). Such a pattern could depress fertility to insemination 0 to $24 \mathrm{hr}$ after the observation of oestrus.

The observed difference between 30 to 60 day non-return rate and the data 
from pregnancy diagnosis shows the unreliability of the former in experiments of this type. Whether this is related to the progestagen treatment is not clear. The difference in pregnancy rate between A.I.S. and Friesian cows is attributable to a greater number of pregnancies in non-oestrous Friesians. Although the interaction just failed to reach significance, the results are suggestive of a breed difference in response to progestagens.

\section{ACKNOWLEDGMENTS}

Thanks are due to King Ranch (Australia) Pty. Ltd, who provided the heifers and semen used in Experiment 1. Members of their staff, particularly Mr M. Lemann, Mr G. Crouch and Mr P. Stewart-Fox, rendered invaluable technical assistance. Technical assistance was also given by Mr R. J. Scaramuzzi. The authors are grateful to the farmers who allowed the use of their cows in Experiment 2, to the N.S.W. Milk Board for assistance in organization and the supply of semen, to Mr B. J. Doyle, Director of the Berry Artificial Breeding Centre, and to Mr J. Bramley, who did the inseminations in Experiment 2.

The authors also thank Professor T. J. Robinson for helpful advice and criticism in the planning and conduct of the investigation.

This work was supported by a Research Grant from G. D. Searle \& Co.

\section{REFERENCES}

Christian, R. E. \& CASIDA, L. E. (1948) The effects of progesterone in altering the estrus cycle of the cow. F. Anim. Sci. 7, 540 .

Donaldson, L. E. \& Larkin, R. M. (1966) Experiences in artificial insemination of beef cattle in North Queensland. Proc. Aust. Soc. Anim. Prod. 6, 52.

Hansel, W. (1961) Estrous cycle and ovulation control in cattle. F. Dairy Sci. 44, 2307.

Hansel, W., Malven, P. V. \& Black, D. L. (1961) Estrous cycle regulation in the bovine. f. Anim. Sci. 20,621.

LAmond, D. R. (1964) Synchronisation of ovarian cycles in sheep and cattle. Anim. Breed. Abstr. 32, 269.

Nelior, J. E. \& Cole, H. H. (1956) The hormonal control of estrus and ovulation in the beef heifer. F. Anim. Sci. 15, 650.

Quinlivan, T. D. \& Robinson, T. J. (1967) The number of spermatozoa in the Fallopian tubes of ewes at intervals after artificial insemination following SC-9880 impregnated intravaginal sponges. In: The Control of the Ovarian Cycle in the Sheep, Ed. T. J. Robinson. Sydney University Press. (In press.)

RoBrsson, T. J. (1964) Synchronization of oestrus in sheep by intravaginal and subcutaneous application of progestin impregnated sponges. Proc. Aust. Soc. Anim. Prod. 5, 47.

Rosinson, T. J. (1965) Use of progestagen-impregnated sponges inserted intravaginally or subcutaneously for the control of the oestrous cycle in the sheep. Nature, Lond. 206, 39.

Robinson, T. J., Salamon, S., Moore, N. W. \& Smith, J. F. (1967) The evaluation of SC-9880 impregnated intravaginal sponges for the synchronization of oestrus for large scale artificial insemination of Merino ewes in summer and autumn. In: The Control of the Ovarian Cycle in the Sheep, Ed. T. J. Robinson. Sydney University Press. (In press.)

Shelton, J. N. (1964) An assessment of newer progestins for control of oestrus and ovulation in the ewe. Proc. Aust. Soc. Anim. Prod. 5, 43.

Shelton, J. N. (1965) Identification of progestogens of high activity for the control of the oestrous cycle in the sheep. Nature, Lond. 206, 156.

SHelton, J. N. \& MOORE, N. W. (1967) The evaluation of alternative methods of administration of progestagens in the entire cyclic ewe. In: The Control of the Ovarian Cycle in the Sheep. Ed. T. J. Robinson. Sydney University Press. (In press.)

TRImberger, G. W. (1948) Breeding efficiency in dairy cattle from artificial insemination at various intervals before and after ovulation. Res. Bull. Neb. agric. Expl Stn. No. 153. 
Ulberg, L. G., Christian, R. E. \& CAsida, L. E. (1951) Ovarian response in heifers to progesterone injections. F. Anim. Sci. 10, 752.

Vandeplassche, M. \& Paredis, F. (1949) How long does bull sperm maintain its fertilising capacity in the genital tract of the cow? Tijdschr. Diergeneesk. 74, 831. Abstract in Anim. Breed. Abstr. 19, 63.

Zimbelman, R. G. (1961) The control of estrus and ovulation in heifers by orally administered 6 $\alpha$ methyl-17 $\alpha$-acetoxyprogesterone. F. Dairy Sci. 44, 1195. 